\title{
Report of the Managing Director
} to the International Monetary and Financial Committee on the IMF's Policy Agenda 


\section{INTERNATIONAL MONETARY FUND}

\section{Report of the Managing Director to the International Monetary and Financial Committee on the IMF's Policy Agenda}

April 9, 2008

Contents

Executive Summary.

I. Recent Developments in the Global Economy ......................................................... $\underline{5}$

II. Refocusing the Fund's Major Areas of Work ........................................................... $\underline{6}$

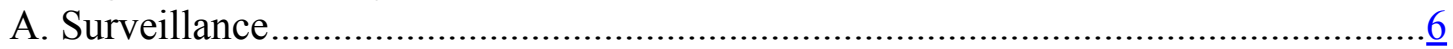

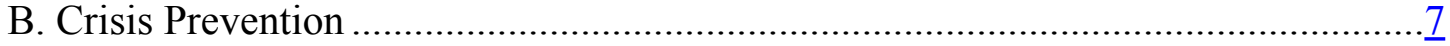

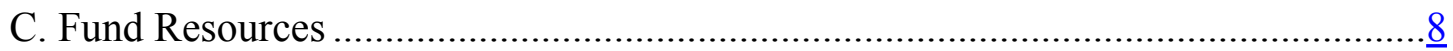

D. Low-Income Members ...................................................................................... $\frac{9}{2}$

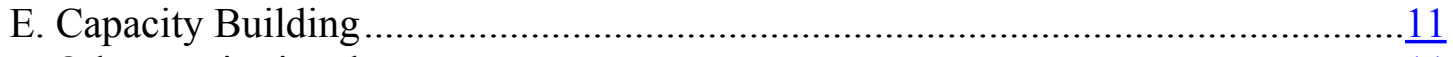

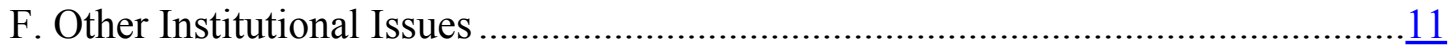

III. Setting the Fund on a Sustainable Financial Footing............................................. 12

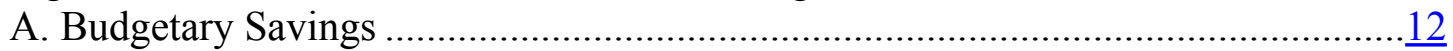

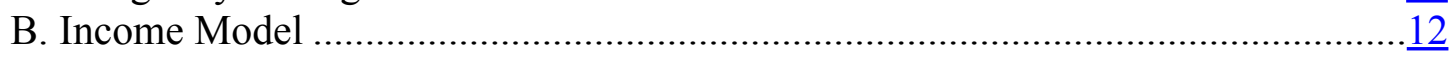

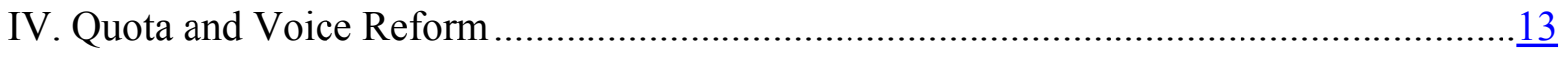

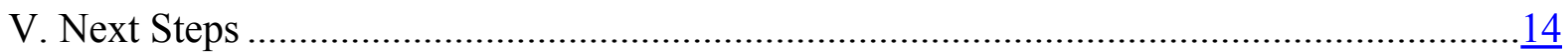




\section{Text Boxes}

1. Re-Prioritizing the Fund's Work with a Reduced Medium-Term Budget

2. Implementation of the Medium-Term Strategy: A Stocktaking of Progress Achieved...... 16

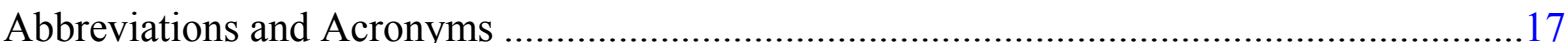

\section{Tables}

1. Participation in Transparency, FSAP, and Standards and Codes Initiatives $\underline{18}$

2. Participation in FSAPs and FSAP Updates

3. Implementation of the HIPC Initiative and MDRI

4. Current Financial Arrangements and PSIs

5. Total Fund Credit and Loans Outstanding to the Ten Largest Borrowers.

6. Consolidated Income and Expenses for the Fund (FY 2008-14)

Annex

Summary of MCM Working Group Policy Recommendations 


\section{EXECUTIVE SUMMARY}

We meet at a time of unprecedented turmoil in global financial markets and great uncertainty about global economic prospects. The response of the international community, and especially of the International Monetary Fund, must be commensurate with the challenges our members face. This paper describes the policy changes that the Fund has made since the October 2007 IMFC meeting and the ways in which we plan to refocus the Fund's work to support our members more strongly. It also describes the steps that management, staff, and the Executive Board have agreed to put our own house in order - to reform our governance, contain our spending, and solve our income problem.

An exceptional effort to refocus and modernize the Fund's structures and activities is well-advanced. The central idea is that the principle of comparative advantage should guide our work in all areas. In surveillance this means a greater focus on the linkages between national economies and the global economy and between financial markets and the real economy. Understanding these linkages is essential if we are to manage the current crisis. In our work on low-income countries it means that we should concentrate on helping our members achieve and maintain macroeconomic stability, which is a necessary condition for raising growth and reducing poverty. In our work on capacity-building it means that technical assistance will be made more demand-driven by the introduction of charges graduated according to per capita income, will be augmented by more fund raising, and will be prioritized based on the Fund's core mandate, comparative advantage, and avoiding overlaps with other providers. The strategy is described more fully in my statement on Strategic Directions in the Medium-Term Budget, which I have separately sent to you. ${ }^{1}$

The Board has also finalized a package of quota and voice reforms - another key element of the strategy. The reform package, currently being considered by the Board of Governors, fully meets the objectives laid out in Singapore, which were (i) to make significant progress in realigning quota shares with economic weight in the global economy, and to make quota and voting shares more responsive to global economic realities in the future; and (ii) equally importantly, to enhance the participation and voice of low-income members. A separate paper on quota and voice reform is also being sent to the IMFC. ${ }^{2}$

The Board has reached agreement on the steps necessary to put the Fund's finances in order, by agreeing a new income and expenditure framework.

- $\quad$ On the expenditure side, the Fund has moved rapidly to identify approximately US\$100 million in annual savings in real terms by the third year of the medium-term budget, including through sizeable reductions in staff, and has set out how a leaner and refocused institution will better serve its membership.

\footnotetext{
${ }^{1}$ Strategic Directions in the Medium-Term Budget-Statement by the Managing Director (to be published on www.imf.org).

${ }^{2}$ Report of the Managing Director to the International Monetary and Financial Committee on IMF Quota and Voice Reform (to be published on www.imf.org).
} 
- $\quad$ On the income side, the Executive Board has agreed to revamp the Fund's income model from one that relies primarily on lending to one that generates funds from new sources, including an endowment created through limited gold sales and a broader investment mandate. This needs to be followed up expeditiously by national authorities to make the new income model effective.

Considerable work has been done in recent months on the causes, impact, and potential responses to the current financial crisis. The impact of the crisis on global stability and growth is a central topic of the current World Economic Outlook (WEO), and the Global Financial Stability Report (GFSR) provides an analysis and recommendations for the international financial system, both for the private and public sectors in the short and longer term. Potential spillovers from the financial crisis are assessed, looking at real and financial transmission channels, including tail risks for the global economy from a deeper financial and economic downturn that could reinforce each other. The Fund provides a unique forum for multilateral discussion of these issues, and is also working with other international bodies to help draw lessons and frame policy responses. In addition, we are drawing heavily on the analysis in the $\underline{\mathrm{WEO}}$ and GFSR, and on deeper financial sector analysis more generally, in our consultations with member countries.

The remainder of the paper reports in more detail on work that has been completed and is underway. Section I discusses recent developments in the global economy, and the Fund's response. Section II explains how the Fund's major areas of work are being refocused. Section III describes efforts to set the Fund on a sustainable financial footing. Section IV gives an update on progress on quota and voice reform. Proposed next steps are set out in Section V. 


\section{RECENT DEVELOPMENTS IN THE GLOBAL ECONOMY}

1. The financial crisis has slowed world growth, and the process of restoring confidence in the financial system will be complex and protracted. The slowdown has been greatest in advanced economies; emerging and developing economies have so far been less affected and continued to grow at a rapid pace. The latest $\mathrm{WEO}$ projects global growth to slow to 3.7 percent in 2008 from 4.9 percent in 2007, with growth in emerging and developing countries also projected to decelerate but expected to still remain relatively robust. ${ }^{3}$ Risks to the outlook remain tilted to the downside, with the greatest risk coming from the still unfolding events in financial markets and their potential impact on economic activity. Exchange rate movements have been orderly but have fallen disproportionately on currencies with flexible exchange rate regimes, and may, as a result, be producing new misalignments or fueling protectionist sentiment. Inflation pressures have risen worldwide, with sharply higher food and energy prices partly reflecting a sluggish supply response, as well as strong domestic demand in a number of emerging and developing economies. The latest GFSR expects risks to global financial stability to remain elevated during $2008 .{ }^{4}$

\section{The Fund has been developing policy proposals to deal with the present financial crisis and draw lessons from it.}

- $\quad$ The Board on April 4 discussed an initial assessment of the crisis, and broadly supported a set of preliminary lessons and recommendations in the areas of: risk management practices related to structured finance products; the role and design of credit ratings of structured products; the valuation, accounting and disclosure of structured products; crisis and emergency liquidity management, including by central banks; and the regulation and prudential oversight of banks and other financial entities (see Annex). ${ }^{5}$ While recognizing that the financial crisis was still evolving, Executive Directors underlined the importance of analyzing its causes to begin drawing tentative lessons that could inform the Fund's surveillance. They encouraged staff to continue to work closely and proactively with national authorities, international bodies, and market participants to draw and disseminate lessons from the crisis.

- $\quad$ At the bilateral level, the Fund continues its efforts to deliver country assessments and updates under the joint Fund-Bank Financial Sector Assessment Program (FSAP) (see Table 2) and to step up financial sector analysis in Article IV consultations.

- $\quad$ Other continuing work to strengthen financial stability is summarized in Section II.B.

\footnotetext{
${ }^{3}$ April 2008 WEO.

${ }^{4}$ April 2008 GFSR.

${ }^{5}$ The Recent Financial Turmoil - Initial Assessment, Policy Lessons, and Implications for Fund Surveillance $(4 / 9 / 08)$.
} 


\section{REFOCUSING THE FUND's MAJOR AREAS OF WORK}

3. This section reviews the efforts underway to refocus and modernize the work of the Fund. The Fund's new strategic vision-described in the Strategic Directions in the Medium-Term Budget-refocuses the Fund's priorities in order to adapt to a changing world and a reduced budgetary envelope (see Box 1), building on progress achieved under the Medium-Term Strategy (see Box 2).

\section{A. Surveillance}

4. Surveillance is at the core of the Fund's mandate. More emphasis is being put on strengthening the Fund's multilateral perspective in bilateral surveillance and improving its analysis of linkages between the real economy and the financial sector.

\section{Work on implementation of the 2007 Decision on surveillance over members' exchange rate policies, and more generally enhancing bilateral surveillance, is continuing.}

- $\quad$ Key operational aspects in implementing the 2007 Surveillance Decision-in force since its adoption in June 2007-are being clarified. The Surveillance Guidance Note is expected to be updated after the Spring Meetings. Prior to that update, Executive Directors will have an opportunity to exchange views on the concepts and methodologies for assessing external stability, analyzing exchange rates and current account positions, and assessing exchange rate policies. These issues are already receiving much more attention in Article IV consultations.

- $\quad$ Staff reports on Article IV consultations are being rethought to make the outputs of surveillance more timely and less paper-intensive, which should enhance their impact. Executive Directors will have an opportunity to express views on examples of concise staff reports, to help make sure this evolution does not have an adverse impact on the depth of analysis or the quality of the policy dialogue with members.

- Implementation of data reporting for surveillance purposes will be strengthened. At a Board meeting in May, Directors will consider a periodic review of the overall framework for data reporting, including possible ways of improving its implementation.

- $\quad$ After the Spring Meetings, the Board will review the system and methodology used to classify member countries' de facto exchange rate arrangements to clarify the definitions of the various categories and establish more operational and unambiguous criteria for their application.

6. The multilateral and cross-country perspectives in surveillance are being enhanced. The Fund's bilateral, regional, and multilateral surveillance provides a unique basis for regionally and globally relevant and coherent policy advice. Efforts aim at enhancing the impact of existing instruments and initiatives (the $\underline{\text { WEO}}$, the GFSR, the Fund's crisis preparedness work, and more recently, work on SWFs), and bolstering cross-country perspectives, including through better communication. Two recent Board seminars examined 
how fiscal policy can contribute to realizing the benefits of globalization and financial deepening and address related challenges, and the fiscal implications of climate change. ${ }^{6}$

7. Macro-financial linkages are receiving more attention. Recent initiatives include analytical and policy-related work on the impact on economic activity of the current financial crisis; more emphasis on macro-financial linkages in the conjunctural sections of the WEO; greater focus on financial sector analysis in Article IV consultations and continued emphasis on FSAPs; internal training on financial sector issues; data collection initiatives that focus on the position of financial institutions vis-à-vis other sectors and the associated risks; and analytical and empirical work on how financial and real sector reforms complement each other.

8. The 2008 Triennial Surveillance Review (TSR) will provide an opportunity to discuss strategic issues related to refocusing surveillance. An informal Board meeting in April, based on an Issues Note, will give Directors an opportunity to discuss the design of the TSR. The envisaged Statement of Surveillance Priorities should help focus surveillance work across the Fund, underpin the policy dialogue with members, and enhance accountability.

9. The Board discussed issues surrounding Sovereign Wealth Funds (SWFs) and most Directors agreed that the Fund is well placed to facilitate and coordinate work on best practices for SWFs. ${ }^{7}$ SWFs are becoming more prominent in international financial markets. They offer various economic benefits and can play a stabilizing role in international financial markets, but some concerns have been voiced regarding their size, transparency, and that their investments may be affected by non-commercial considerations. The Fund will engage in a dialogue with members and SWFs to facilitate and coordinate the development of a set of voluntary best practices to enhance understanding and transparency of SWFs, which could help the undertaking of SWFs' operations and reduce protectionist pressure against SWFs. A survey has been sent to SWFs and an international working group of SWFs will be established, with the aim to discuss at the Board a draft document before the 2008 Annual Meetings.

\section{B. Crisis Prevention}

10. Financial globalization has amplified the need for a global perspective in assessing and dealing with vulnerabilities. The Fund's efforts in monitoring vulnerabilities dovetail with its surveillance activities.

\section{Work on monitoring risks at the country, regional, and global level is being} strengthened.

- In light of recent financial market turmoil, work is underway to strengthen analysis of vulnerabilities in advanced economies and collaboration with standard setters, central

\footnotetext{
${ }^{6}$ IMF Executive Board Holds Seminar on Globalization, Financial Markets, and Fiscal Policy (PIN/08/28, 2/29/08) and IMF Executive Board Holds Seminar on the Fiscal Implications of Climate Change (PIN/08/44, $4 / 3 / 08)$.

${ }^{7}$ IMF Executive Board Discusses a Work Agenda on Sovereign Wealth Funds (PIN/08/41, 4/1/08).
} 
banks, and finance ministries, for example in conjunction with the Financial Stability Forum (FSF) as well as the G-20. For this purpose, a Global Financial Stability Note has been prepared for the March 2008 FSF meeting. Also, an analysis of tail risks to the global economy/financial system, particularly the major advanced countries, together with possible macro-financial early warning indicators, will be presented to the IMFC during the Spring Meetings.

- $\quad$ The vulnerability exercise, established in 2001, provides regular cross-country assessments of vulnerabilities and crisis risks in emerging market economies. The Spring 2008 exercise focused on the impact of global turmoil on emerging market economies and the risk that asset price booms could end in sharp corrections. The exercise will be extended to advanced economies.

- $\quad$ After the Spring Meetings, the Board will discuss a paper on financial crises of the future, which will include a discussion of how financial innovations have affected the transmission channels of financial crises and the potential implications for the Fund. The paper analyzes new issues the Fund could face and appropriate responses, including the work already underway to strengthen crisis preparedness, and financial stability surveillance, as well as program design, the Fund's instruments, and coordination with the official and private sectors.

12. The Fund continues to explore whether its financial instruments meet the needs of emerging market economies. There has been some encouraging support for the Rapid Access Line (RAL), designed to meet the needs of these economies. ${ }^{8}$ Members, however, continue to have mixed views about some elements of the design, and a consensus for an instrument that would be useful and actually used has not been reached. The Fund will expedite its work on developing a new liquidity instrument, and in taking this forward, consider also suggestions made by some Executive Directors for a financial stability line for countries integrating into global capital markets and pursuing financial sector reforms.

\section{Fund Resources}

\section{The changing structure of the international economic and financial system requires the Fund to adapt its financing instruments to remain relevant.}

- While the Board completed a periodic review of the Fund's access policy in February and considered that the policy remains broadly appropriate, ${ }^{9}$ a number of Executive Directors, some in the context of the Quota and Voice discussion, saw the need for increasing access limits. The normal access limits have declined as a share of trade and capital flows, and the issue will be looked at again before the Annual Meetings.

\footnotetext{
${ }^{8}$ The instrument's name has been changed from the Reserve Augmentation Line to the Rapid Access Line to better reflect its purpose.

${ }^{9}$ IMF Executive Board Concludes Review of Access Policy in the Credit Tranches and Under the Extended Fund Facility and the Poverty Reduction and Growth Facility, and Exceptional Access Policy (PIN/08/30, 3/7/08).
} 
- The Board discussed how to set the basic rate of charge on the Fund's financing facilities under a new income model (see Section III for the new income model). Directors agreed that the rate of charge should be set to cover the Fund's cost of intermediation, allow for some reserve accumulation, and be broadly aligned with market conditions. Directors also discussed the initial margin for the rate of charge and are expected to take a decision shortly on the margin for FY 2009. Directors looked forward to a review of the adequacy of precautionary balances, and completing the review of the Fund's charges and maturities before end-2008.

- $\quad$ The adequacy of Fund resources was considered in the context of the Thirteenth General Review of Quotas; the Board of Governors concluded the review in January 2008 without an increase in quotas. ${ }^{10}$

\section{Low-Income Members}

14. The Fund remains closely engaged with low-income countries (LICs) and is refocusing its efforts to help them secure and maintain macroeconomic and financial stability, and tackle emerging challenges. Key elements of the Fund's role in LICs are outlined below and will be discussed by the Board after the Spring Meetings:

- $\quad$ The Fund will concentrate on its core areas of expertise-macroeconomic policies and institutions that support the stability necessary for sustained growth and poverty reduction - and will do less on non-core structural issues clearly outside the Fund's mandate.

- It will build on cross-country experience and perspectives while providing policy advice tailored to country needs, capacity building assistance, and financial and policy support through programs.

- $\quad$ Some shift in the focus of Fund engagement is expected, particularly as countries grow and mature, with greater emphasis on the policy response to capital inflows, commodity price swings, financial market development, and debt sustainability in light of substantial debt relief and new financing sources.

- $\quad$ Cooperation with the World Bank and donors will be strengthened, including through implementation of the Joint Management Action Plan (JMAP) and pilot projects involving closer coordination in the areas of public financial management, the financial sector, and natural resource management in a number of African countries.

- $\quad$ World Bank and Fund staffs will continue to track progress toward the Millennium Development Goals (MDGs) as was done in the joint 2008 Global Monitoring Report. ${ }^{11}$

\footnotetext{
${ }^{10}$ IMF Executive Board Recommends to Governors Conclusion of Thirteenth General Quota Review (PR/08/02, 1/4/08) and IMF Board of Governors Approves Conclusion of Quota Review (PR/08/13, 2/4/08).

${ }^{11}$ Progress toward nutrition, health, education, and other development goals off track, Global Monitoring Report Finds (PR/08/75, 4/8/08).
} 
15. LIC work is being streamlined and reviewed. Streamlining the production of Joint Staff Advisory Notes (JSANs) as well as Poverty Reduction and Growth Facility (PRGF) and Policy Support Instrument (PSI) reviews will be taken up after the Spring Meetings to increase efficiency and reduce paper flow. Ex post assessments could be used more selectively, while still providing independent assessments of program effectiveness. The PSI, which has five current users (Table 4), and the Exogenous Shocks Facility (ESF) will be reviewed.

16. Additional countries have benefited from debt relief under the Heavily Indebted Poor Countries (HIPC) Initiative and Multilateral Debt Relief Initiative (MDRI), and changes have been introduced to the HIPC framework to reduce delays in the process for HIPCs with protracted arrears to the Fund or other multilateral institutions.

- $\quad$ Performance under Staff-Monitored Programs that have been found by the Executive Board to meet the upper credit tranche policy standard - as under the PRGF - may count toward the track record of performance needed to reach the HIPC Initiative decision point. $^{12}$

- $\quad$ Liberia, one of three HIPC-eligible countries with protracted arrears to the Fund, was the first to benefit from the above change and reached its decision point in March.

- $\quad$ To date, 33 members have reached their HIPC Initiative decision point and 23 have reached their completion point. Twenty-five members have received Fund debt relief under the MDRI.

17. Helping LICs maintain debt sustainability remains a top priority. A project aimed at enhancing LICs' debt management capacities has been initiated with the World Bank, and training is being provided to country officials to enable them to use the Debt Sustainability Framework (DSF) as a policy tool. On the creditor side, the Fund has built on the commitment of major development banks to use the DSF in tailoring financing terms. Fund staff worked closely with the OECD's export credit group to define the sustainable lending principles agreed in January. The principles commit OECD export credit agencies to observe IMF and World Bank concessionality requirements in LICs where they exist, and to take into account the results of debt sustainability analyses for other LICs. Measures have been taken to enhance information sharing with all creditors, including through the creation of a dedicated web-based mailbox. Outreach efforts continue, especially towards non-OECD creditors. Advice to LICs on borrowing strategies will be refined.

18. The Board welcomed the review of the Fund's engagement with fragile states and post-conflict countries, and generally agreed that there is scope to improve the effectiveness of the Fund's engagement with low-income fragile states. ${ }^{13}$ Many Directors saw merit in a graduated, flexible, medium-term programmatic approach while a number of other Directors considered that the necessary improvements could be achieved in the context of the

${ }^{12}$ IMF Executive Board Modifies HIPC Initiative (PIN/08/03, 1/17/08).

${ }^{13}$ IMF Executive Board Discusses the Fund's Engagement in Fragile States and Post-Conflict Countries-A Review of Experience (PIN/08/43, 4/1/08). 
Fund's existing toolkit of technical assistance, surveillance, assessment letters, staff-monitored programs, and EPCA. Management will return to the Board with a follow-up paper with operational proposals that reflect the Board's views and the results of planned outreach to potential recipients and donors.

\section{E. Capacity Building}

19. The Board will consider a number of recommendations to strengthen the effectiveness and efficiency of the Fund's capacity building program after the Spring Meetings:

- $\quad$ Proposed reforms focus on enhancing the integration of TA with surveillance and lending activities; strengthening prioritization of TA, including through charging graduated according to per capita income, as well as coordination with recipients and other TA providers; and bringing Fund work in line with best international practice, particularly on costing and results-focused project management. This will set the stage for a stronger partnership with the Fund's donors and allow the Fund to scale up our regional work and establish trust funds in areas of our comparative advantage and where our TA is needed most (such as fragile states).

- $\quad$ Greater dissemination of TA information would leverage the effectiveness of Fund capacity-building efforts.

- $\quad$ For training of country officials, the Fund would shift shorter courses from headquarters to co-financed locations abroad, introduce charges for courses at headquarters, and seek additional external funding to help recover costs.

\section{F. Other Institutional Issues}

20. The Fund continues to strengthen risk management. The Board welcomed the Advisory Committee on Risk Management's update report_-which gave particular emphasis to new risks stemming from the refocusing and downsizing exercise - at an informal Board briefing in January with some calls to reflect a greater prioritization in the risk management framework and to consider risks from misreporting. Also in January, in a briefing to the Board, the External Audit Committee indicated satisfaction with the Fund's internal and external audit processes, and encouraged steps to make Fund financial statements clearer, implement the Fund's whistleblower policy, and adopt a more formalized incident-reporting process.

21. Efforts continue to improve collaboration between the IMF and World Bank. The JMAP is now being implemented. Country-level work program discussions have been initiated for low- and middle-income countries and will be expected annually. Also, a number of country teams and functional areas are in the process of piloting new ways to use information technology to promote more effective interaction.

22. The Board considered an Independent Evaluation Office (IEO) assessment of structural conditionality and the implementation of earlier IEO recommendations 
endorsed by the Board. ${ }^{14} 15$ The Board welcomed the IEO's finding that the composition of structural conditionality has shifted toward Fund core areas and called for greater streamlining and focus, strong justification for non-core conditions, and better articulation of links between program goals and conditionality. A Management Implementation Plan (MIP) has been developed. The Board also welcomed the first Periodic Monitoring Report on Board-endorsed IEO recommendations, noted the substantial impact of IEO recommendations to date, and emphasized the importance of using well-defined and measurable criteria, to the extent possible, in future MIPs. ${ }^{16}$ The Board will consider IEO findings on the Fund's corporate governance after the Spring Meetings while the IEO work program for future evaluations includes the Fund's interactions with member countries, its research agenda, and its approach to international trade issues.

\section{Setting the Fund on a Sustainable Financial Footing}

23. Milestone Board decisions have been taken on budget savings and on adoption of a new income model to secure the Fund's financial sustainability. ${ }^{17}{ }^{18}$ The Board approved a new budgetary envelope that will deliver annual real savings of US\$100 million over the medium term. The Board also agreed to a package of new income sources to raise annual revenues over the medium term to fill the remaining income shortfall.

\section{A. Budgetary Savings}

24. The Board approved a budgetary envelope that will deliver US\$100 million in annual savings in real terms compared to the current medium-term budget. About one-third of the savings are in non-staff costs, and about two-thirds were achieved by cutting 380 staff positions. Over 60 percent of the staff downsizing is expected to occur in FY 2009. To underpin and contribute to these savings, the Fund is modernizing its business practices and refocusing its activities. A restructuring of this magnitude is unprecedented at the Fund.

\section{B. Income Model}

25. The Executive Board has reached agreement on the steps necessary to mobilize new income sources, building on the recommendations from the Committee of Eminent

\footnotetext{
${ }^{14}$ Structural Conditionality Study-IEO Evaluates IMF Loan Conditions (IMF Survey, 1/3/08).

${ }^{15}$ Progress Report on the Activities of the Independent Evaluation Office (to be published on www.imf.org).

${ }^{16}$ First Periodic Monitoring Report on the Status of Board-Endorsed Recommendations of the Independent Evaluation Office (PIN/08/25, 2/26/08).

${ }^{17}$ IMF Managing Director Strauss-Kahn Applauds Executive Board's Landmark Agreement on Fund's New Income and Expenditure Framework (PR/08/74, 4/7/08).

${ }^{18}$ Report of the Managing Director to the International Monetary and Financial Committee on a New Income and Expenditure Framework for the International Monetary Fund (to be published on www.imf.org).
} 
Persons. ${ }^{19}$ Specifically, the Executive Board has recommended the Board of Governors' approval of a proposed amendment of the Fund's Articles of Agreement to expand the Fund's investment authority. Moreover, all Executive Directors have indicated either that they are ready to vote in favor of selling the Fund's current stock of post-Second Amendment Gold to create an endowment, or that they will seek approval from their domestic legislature to enable them to vote in favor of such a sale. The Executive Board has also decided to resume the annual reimbursement of the General Resources Account for the administrative expenses of the PRGF-ESF Trust, to begin in the financial year that the Fund adopts a decision authorizing the sale of gold. To ensure that this cost recovery will not affect the Fund's ability to provide concessional lending to low-income countries, the Executive Board also decided that the Fund should temporarily suspend annual reimbursements if the resources of the Trust are likely to be insufficient to support anticipated demand, while the Fund engages donors with a view to restoring the Trust's sustainability.

26. Timely and broad support from the membership is needed to make the proposed new income model effective. Entry into force of the proposed amendment to broaden the Fund's investment authority will require approval by the Board of Governors by a majority of votes cast, and acceptance by three-fifths of the members having 85 percent of the total voting power-which would require legislative approval by many members. A Board decision to authorize gold sales also requires an 85 percent majority of the total voting power.

\section{QUOTA AND VOICE REForm}

27. On March 28, the Executive Board recommended the adoption by the Board of Governors of an important package of quota and voice reforms, with the Board of Governors to vote on the reform by April $28 .{ }^{20}$ The package includes agreement on a new simpler and more transparent quota formula, increased representation for dynamic economies, and amendments to the Articles to (i) triple basic votes and maintain the share of basic votes in total votes going forward, and (ii) to enable Executive Directors elected by a large number of members to appoint an additional Alternate Executive Director. The package also includes agreement that the Executive Board will recommend further realignments of quota shares in the context of future general quota reviews, beginning with the Fourteenth General Review of Quotas. The Report of the Managing Director to the IMFC on IMF Quota and Voice Reform provides more details of the reform package.

\footnotetext{
${ }^{19}$ Eminent Persons Group Outlines Long-Term Revenue Plan to Finance IMF Activities (PR/07/18, 1/31/07). The Committee's proposal to invest quota resources has not yet gained sufficiently broad support from the membership to make it a viable component of the new income model.

${ }^{20}$ IMF Executive Board Recommends Reforms to Overhaul Quota and Voice (PR/08/64, 3/28/08).
} 


\section{NeXt STEPS}

28. Beyond the Spring Meetings, in addition to implementing identified cost savings, the Fund will seek to move forward on a number of specific objectives consistent with the overall strategy for refocusing and revitalizing the Fund. These include:

- $\quad$ Further lessons and recommendations will be distilled from the current credit market crisis.

- $\quad$ An updated Surveillance Guidance Note, the TSR, and especially efforts to strengthen and integrate financial sector work and draw on multilateral perspectives, will help strengthen the Fund's global and bilateral surveillance.

- Work will continue to facilitate and coordinate the development of best practices for SWFs.

- Work on the RAL will be expedited and access levels will be looked at again.

- $\quad$ The adequacy of precautionary balances will be reviewed and the review of the Fund's charges and maturities will be completed before end-2008.

- $\quad$ The Fund's role in LICs will be discussed, streamlining of JSANs and PRGF/PSI reviews will be pursued, the PSI and ESF will be reviewed, a follow-up paper on fragile states with operational proposals reflecting Board views will be discussed, and borrowing strategies for LICs will be considered.

- $\quad$ Proposals to enhance the impact of capacity building, strengthen its governance including through costing, introduce a framework for charging, lay out a corporate fundraising strategy, and disseminate TA reports more widely will be considered. 
Box 1: Re-Prioritizing the Fund's Work with a Reduced Medium-Term Budget

Doing More

Doing Less

\section{Surveillance}

More focused consultations

Cross-country analysis

Macro-financial linkages

Coverage of financial issues

International linkages and spillovers

Review

Standard consultations with wide coverage

Program work in emerging market economies

Selected Issues papers in non-core areas

\section{Low-Income Countries}

Engagement with donors

Coordination on low-income issues

Building on lessons from emerging economies

Work on HIPC/MDRI

Ex post assessments

Joint Staff Advisory Notes

\section{Capacity Building}

TA/Training (External-Financed)

TA/Training through RTACs

Reports on Standards and Codes

TA/Training (Fund-Financed)

Work on Anti-Money Laundering and Combating

Financing of Terrorism 


\begin{tabular}{|c|c|}
\hline \multicolumn{2}{|r|}{$\begin{array}{l}\text { Box 2: Implementation of the Medium-Term Strategy: } \\
\text { A Stocktaking of Progress Achieved in Key Areas }\end{array}$} \\
\hline Objective & Action \\
\hline $\begin{array}{l}\text { Modernizing Surveillance } \\
\text { - A more global perspective } \\
\text { - } \quad \text { Effective country surveillance }\end{array}$ & $\begin{array}{l}\text { Multilateral Consultation on global imbalances to foster cooperative action. Renewing the } \\
\text { foundations of bilateral surveillance through adoption and implementation of the } 2007 \\
\text { Decision. Strengthened focus on spillovers and cross-country experience. Quarterly updates } \\
\text { of WEO and GFSR. Expansion of regional surveillance. } \\
\text { Enhanced financial sector coverage, refined tools for assessments of exchange rates, and } \\
\text { integration of analysis from WEO and GFSR and assessments of vulnerabilities into } \\
\text { surveillance work. }\end{array}$ \\
\hline $\begin{array}{l}\text { The Changing Role of the Fund } \\
\text { in Emerging Market Economies } \\
\text { - Centrality of financial and } \\
\text { capital market issues } \\
\text { Crisis prevention }\end{array}$ & $\begin{array}{l}\text { Strengthened coverage of financial and capital markets, provision of advice on deepening } \\
\text { local capital markets, and examination of issues related to capital inflows. } \\
\text { Continued discussions and consultations on a new liquidity instrument to help countries in } \\
\text { their crisis prevention efforts. Updated methodology for assessing underlying vulnerabilities } \\
\text { and exposure to crisis risks in emerging markets. }\end{array}$ \\
\hline $\begin{array}{l}\text { Role of the Fund in Low- } \\
\text { Income Countries } \\
\text { - Aid and the MDGs } \\
\text { - Successful debt relief } \\
\text { - } \quad \text { Focus and flexibility }\end{array}$ & $\begin{array}{l}\text { Review and clarification of the Fund's advice in managing aid inflows, in the Poverty } \\
\text { Reduction Strategy process, and in donor collaboration. Review of progress in attaining the } \\
\text { MDGs, jointly with the Bank, for the Global Monitoring Report. } \\
\text { Implementation of the Multilateral Debt Relief Initiative. Follow-up and outreach on the Debt } \\
\text { Sustainability Framework to help countries benefit from debt relief, while avoiding excessive } \\
\text { reaccumulation of debt. } \\
\text { In addition to the PRGF, adoption of the Policy Support Instrument to provide policy support } \\
\text { to low-income countries that do not want or need Fund financial assistance, and of the } \\
\text { Exogenous Shocks Facility to provide policy support and financial assistance to low-income } \\
\text { countries facing exogenous shocks. }\end{array}$ \\
\hline $\begin{array}{l}\text { Quota and Voice Issues } \\
\text { - } \quad \text { Fair weight and voice }\end{array}$ & $\begin{array}{l}\text { After the first-round ad hoc quota increases agreed in Singapore, Executive Directors backed } \\
\text { a package of quota and voice reforms, including a new quota formula, a second round of ad } \\
\text { hoc increases for dynamic economies, a tripling of basic votes, and an additional Alternate } \\
\text { Executive Director for each of the two African chairs. The Board of Governors is to vote on } \\
\text { the package by April } 28 .\end{array}$ \\
\hline $\begin{array}{l}\text { Building Institutions and } \\
\text { Capacity } \\
\text { - Integrated complements to } \\
\text { surveillance and Fund lending } \\
\text { Enhance governance of technical } \\
\quad \text { assistance }\end{array}$ & $\begin{array}{l}\text { Implementing the medium-term strategy for capacity building and anchoring the allocation of } \\
\text { resources for technical assistance in surveillance and Fund program priorities. Expanding } \\
\text { regional coverage through new AFRITAC in Gabon and a regional training center in India. } \\
\text { Progress toward reforms and improvements in costing, monitoring/evaluation, dissemination, } \\
\text { and financing of technical assistance and training. }\end{array}$ \\
\hline $\begin{array}{l}\text { Managing an Effective } \\
\text { Institution } \\
\text { - } \quad \text { Expenditure restraint } \\
\text { - } \quad \text { New income model } \\
\text { - } \quad \text { Bank-Fund collaboration } \\
\text { - } \quad \text { Communication } \\
\text { - } \quad \text { Streamlining }\end{array}$ & $\begin{array}{l}\text { Approval of a medium-term budget FY2009-11 that will deliver US\$100 million in annual } \\
\text { savings in real terms compared to the current medium-term budget. } \\
\text { Agreement on the steps necessary to mobilize new income sources, building on the } \\
\text { recommendations from the Committee of Eminent Persons. } \\
\text { Formulation and implementation of a Joint Management Action Plan to enhance Bank-Fund } \\
\text { collaboration, based in large part on consideration of the findings of the Malan Report. } \\
\text { Board endorsement of an enhanced communication strategy as a tool for the Fund to build } \\
\text { understanding and consensus around its work and its reform agenda. } \\
\text { Streamlined Board documents and more focused staff reports. }\end{array}$ \\
\hline
\end{tabular}




\section{Abbreviations and Acronyms}

\begin{tabular}{|c|c|}
\hline DSF & Debt Sustainability Framework \\
\hline ESF & Exogenous Shocks Facility \\
\hline FSAP & Financial Sector Assessment Program \\
\hline FSF & Financial Stability Forum \\
\hline GDDS & General Data Dissemination System \\
\hline GFSR & Global Financial Stability Report \\
\hline GRA & General Resources Account \\
\hline HIPC & Heavily Indebted Poor Countries \\
\hline IEO & Independent Evaluation Office \\
\hline IMF & International Monetary Fund \\
\hline IMFC & International Monetary and Financial Committee \\
\hline JMAP & Joint Management Action Plan \\
\hline JSAN & Joint Staff Advisory Note \\
\hline LIC & Low-Income Country \\
\hline $\mathrm{MCM}$ & Monetary and Capital Markets Department \\
\hline MDG & Millennium Development Goals \\
\hline MIP & Management Implementation Plan \\
\hline MDRI & Multilateral Debt Relief Initiative \\
\hline MTS & Medium-Term Strategy \\
\hline OECD & Organization for Economic Co-operation and Development \\
\hline PRGF & Poverty Reduction and Growth Facility \\
\hline PRS & Poverty Reduction Strategy \\
\hline PSI & Policy Support Instrument \\
\hline RAL & Rapid Access Line \\
\hline ROSC & Report on Standards and Codes \\
\hline SDDS & Special Data Dissemination Standard \\
\hline SWF & Sovereign Wealth Fund \\
\hline TA & Technical Assistance \\
\hline TSR & Triennial Surveillance Review \\
\hline WEO & World Economic Outlook \\
\hline
\end{tabular}


Table 1. Participation in Transparency, FSAP, and Standards and Codes Initiatives 1/ 2/ (As of March 31, 2008)

\begin{tabular}{|c|c|c|c|c|c|c|c|c|}
\hline & $\begin{array}{c}(1) \\
\text { Africa }\end{array}$ & $\begin{array}{c}(2) \\
\text { Developing } \\
\text { Asia }\end{array}$ & $\begin{array}{c}(3) \\
\text { Central and } \\
\text { Eastern Europe }\end{array}$ & $\begin{array}{c}\text { (4) } \\
\text { CIS and } \\
\text { Mongolia }\end{array}$ & $\begin{array}{c}\text { (5) } \\
\text { Western } \\
\text { Hemisphere }\end{array}$ & $\begin{array}{c}(6) \\
\text { Middle East }\end{array}$ & $\begin{array}{c}(7) \\
\text { Advanced } \\
\text { Economies }\end{array}$ & $\begin{array}{c}(8) \\
\text { Total IMF } \\
\text { Members }\end{array}$ \\
\hline Number of Members & 51 & 29 & 17 & 13 & 32 & 14 & 29 & 185 \\
\hline \multicolumn{9}{|l|}{ Initiatives } \\
\hline $\begin{array}{l}\text { SDDS Subscriber } 3 / \\
\text { Number of subscribers }\end{array}$ & 3 & 5 & 11 & 7 & 10 & 1 & 27 & 64 \\
\hline $\begin{array}{l}\text { GDDS Participant 4/ } \\
\text { Number of members }\end{array}$ & 41 & 14 & 3 & 4 & 20 & 9 & 0 & 91 \\
\hline $\begin{array}{l}\text { PIN Published } \\
\text { Number of members } 5 / \\
\text { Percentage }\end{array}$ & $\begin{array}{c}50 \\
98 \%\end{array}$ & $\begin{array}{c}28 \\
97 \%\end{array}$ & $\begin{array}{c}17 \\
100 \%\end{array}$ & $\begin{array}{c}12 \\
92 \%\end{array}$ & $\begin{array}{c}31 \\
97 \%\end{array}$ & $\begin{array}{c}14 \\
100 \%\end{array}$ & $\begin{array}{c}29 \\
100 \%\end{array}$ & $\begin{array}{r}181 \\
98 \%\end{array}$ \\
\hline $\begin{array}{l}\text { Article IV Staff Report Published } \\
\text { Number of members } 5 / \\
\text { Percentage }\end{array}$ & $\begin{array}{c}49 \\
96 \%\end{array}$ & $\begin{array}{c}24 \\
83 \%\end{array}$ & $\begin{array}{c}17 \\
100 \%\end{array}$ & $\begin{array}{c}12 \\
92 \%\end{array}$ & $\begin{array}{c}28 \\
88 \%\end{array}$ & $\begin{array}{c}11 \\
79 \%\end{array}$ & $\begin{array}{c}29 \\
100 \%\end{array}$ & $\begin{array}{r}170 \\
92 \%\end{array}$ \\
\hline $\begin{array}{l}\text { FSAPs Completed } \\
\text { Number of members } 6 / \\
\text { Percentage }\end{array}$ & $\begin{array}{c}22 \\
43 \%\end{array}$ & $\begin{array}{c}5 \\
17 \%\end{array}$ & $\begin{array}{c}17 \\
100 \%\end{array}$ & $\begin{array}{c}9 \\
69 \%\end{array}$ & $\begin{array}{c}20 \\
63 \%\end{array}$ & $\begin{array}{c}11 \\
79 \%\end{array}$ & $\begin{array}{c}26 \\
90 \%\end{array}$ & $\begin{array}{r}110 \\
59 \%\end{array}$ \\
\hline $\begin{array}{l}\text { FSAP Updates Completed } \\
\text { Number of members } \\
\text { Percentage }\end{array}$ & $\begin{array}{c}7 \\
14 \%\end{array}$ & $\begin{array}{c}1 \\
3 \%\end{array}$ & $\begin{array}{c}3 \\
18 \%\end{array}$ & $\begin{array}{c}5 \\
38 \%\end{array}$ & $\begin{array}{c}6 \\
19 \%\end{array}$ & $\begin{array}{c}3 \\
21 \%\end{array}$ & $\begin{array}{c}5 \\
17 \%\end{array}$ & $\begin{array}{c}30 \\
16 \%\end{array}$ \\
\hline ROSC Modules & & & & & & & & \\
\hline $\begin{array}{l}\text { Modules completed 8/ } \\
\text { (Percent of total modules) }\end{array}$ & $\begin{array}{r}156 \\
18 \%\end{array}$ & $\begin{array}{l}70 \\
8 \%\end{array}$ & $\begin{array}{c}161 \\
19 \%\end{array}$ & $\begin{array}{l}82 \\
9 \%\end{array}$ & $\begin{array}{r}146 \\
17 \%\end{array}$ & $\begin{array}{l}55 \\
6 \%\end{array}$ & $\begin{array}{r}199 \\
23 \%\end{array}$ & $\begin{array}{c}869 \\
100 \%\end{array}$ \\
\hline Number of members $7 /$ & 33 & 15 & 17 & 11 & 24 & 11 & 28 & 139 \\
\hline (Percent) & $65 \%$ & $52 \%$ & $100 \%$ & $85 \%$ & $75 \%$ & $79 \%$ & $97 \%$ & $75 \%$ \\
\hline Modules published 8/ & 104 & 48 & 149 & 56 & 89 & 27 & 186 & 659 \\
\hline (Percent of completed modules) & $67 \%$ & $69 \%$ & $93 \%$ & $68 \%$ & $61 \%$ & $49 \%$ & $93 \%$ & $76 \%$ \\
\hline Number of members & 29 & 15 & 17 & 11 & 22 & 9 & 28 & 131 \\
\hline (Percent) & $57 \%$ & $52 \%$ & $100 \%$ & $85 \%$ & $69 \%$ & $64 \%$ & $97 \%$ & $71 \%$ \\
\hline
\end{tabular}

Sources: IMF; and World Bank staff estimates.

1/ This table includes territories, special administrative regions (SARs), and monetary unions only for SDDS, GDDS and ROSCs, and not for other data categories. SDDS subscribers include Hong Kong SAR; GDDS participants include West Bank and Gaza, and Macao SAR; and data for ROSC modules include 19 completed and published modules for Hong Kong SAR, Kosovo, the European Union, the ECCB, and CEMAC. FSAPs and ROSCs for the following entities are included in the number of FSAPs and of ROSC modules for the following regions

but the entities are not counted in the number of members: CEMAC and WAEMU as part of Africa; Kosovo as part of Central and Eastern Europe; ECCB as part of Western Hemisphere; West Bank-Gaza as part of Middle East; European Union and Hong Kong SAR as part of Advanced Economies. 2/ The regional groupings are based on the composition of World Economic Outlook (WEO) groups.

3/ The SDDS was established in 1996 to guide countries that have, or might seek, access to international capital markets in the dissemination of economic and financial data to the public. The table includes subscribers in full observance only.

4/ The GDDS was established in 1997 to encourage members to improve data quality, provide a framework for evaluating needs for data improvement and setting priorities in this respect, and guide members in the dissemination to the public of comprehensive, timely, accessible, and reliable economic, financial, and socio-demographic statistics.

5/ The number of members that have consented to the publication of at least one such document; adjusted to avoid double counting (Serbia, Montenegro). 6/ Excludes FSAPs completed by non-members; specifically, CEMAC, ECCU, and Hong Kong SAR.

7/ The number of members for which at least one ROSC module has been completed. ROSC modules not derived from an FSAP are considered completed once they have been circulated to Directors, and in the case of Bank-led modules, sent in their final form to the authorities.

ROSC modules derived from an FSAP are considered completed when the FSSA has been discussed by the Executive Board.

$8 /$ Shows the total number of completed modules. A member can have more than one full assessment for the same standard. The table includes 19 completed and published modules for Hong Kong SAR, Kosovo, the European Union, the ECCB, and CEMAC.

\section{CInternational Monetary Fund. Not for Redistribution}


Table 2. Participation in FSAPs and FSAP Updates

(As of March 31, 2008)

\begin{tabular}{|c|c|c|c|}
\hline \multicolumn{2}{|c|}{ FSAPs Completed 1/ } & \multirow{2}{*}{$\begin{array}{l}\text { FSAP Updates Completed 1/ } \\
\text { Algeria }\end{array}$} & \multirow{2}{*}{$\begin{array}{l}\text { Under Way 3/ } \\
\text { FSAPs }\end{array}$} \\
\hline Albania & Kyrgyz Republic & & \\
\hline Algeria & Latvia 6/ & Armenia & Burkina Faso \\
\hline Armenia & Lebanon 2/ & Canada 2/ & Central African Republic \\
\hline Australia & Lithuania 6/ & Colombia 2/ & Fiji \\
\hline Austria 6/ & Luxembourg & Costa Rica & Malawi \\
\hline Azerbaijan & Macedonia, FYR 6/ & Egypt & Mali 5/ \\
\hline Bahrain & Madagascar & El Salvador 2/ & Mongolia \\
\hline Bangladesh & Malta & Georgia & Tajikistan \\
\hline Barbados 6/ & Mauritania & Ghana & Thailand \\
\hline Belarus & Mauritius & Guatemala & WAEMU \\
\hline Belgium & Mexico & Hungary $2 / 7 /$ & \\
\hline Bolivia & Moldova & Iceland & FSAP Updates \\
\hline Bosnia and Herzegovina & Montenegro & Ireland 2/ & Austria \\
\hline Botswana & Morocco 6/ & Kazakhstan 2/ & Barbados \\
\hline Brazil & Mozambique & Kyrgyz Republic & Cameroon \\
\hline Bulgaria & Namibia & Lebanon $2 /$ & Croatia \\
\hline Cameroon 2/ 6/ & Netherlands & Mauritius & Estonia \\
\hline Canada $2 /$ & New Zealand & Mexico & Honduras \\
\hline CEMAC 4/ & Nicaragua & Moldova & Kazakhstan \\
\hline Chile & Nigeria & Peru & Latvia \\
\hline Colombia 2/ & Norway & Poland & Lithuania \\
\hline Costa Rica & Oman & Senegal & Macedonia, FYR \\
\hline Croatia 6/ & Pakistan & Slovak Republic & Morocco \\
\hline Czech Republic & Paraguay & Slovenia & Russian Federation \\
\hline Denmark & Peru & South Africa 2/ 7/ & Ukraine \\
\hline Dominican Republic & Philippines & Sri Lanka & \\
\hline ECCU & Poland & Switzerland & Future Participation Confirmed \\
\hline Ecuador & Portugal & Tunisia & \\
\hline Egypt & Qatar & Uganda & FSAPs \\
\hline El Salvador 2/ & Romania & United Arab Emirates & Angola \\
\hline Estonia 2/ 6/ & Russian Federation 6/ & & Burundi \\
\hline Finland & Rwanda & & Cape Verde \\
\hline France & Saudi Arabia & & Chad \\
\hline Gabon & Senegal & & China \\
\hline Georgia & Serbia & & Cote d'Ivoire \\
\hline Germany & Sierre Leone & & Cyprus \\
\hline Ghana & Singapore & & Djibouti \\
\hline Greece & Slovak Republic & & Equatorial Guinea \\
\hline Guatemala & Slovenia & & Guinea \\
\hline Guyana & South Africa 2/ 7/ & & Niger $5 /$ \\
\hline Haiti & Spain & & Republic of Congo \\
\hline Honduras 6/ & Sri Lanka & & San Marino \\
\hline Hong Kong SAR & Sudan & & Syrian Arab Republic \\
\hline Hungary 21 & Sweden & & United States \\
\hline Iceland & Switzerland & & \\
\hline India 2/ & Tanzania & & FSAP Updates \\
\hline Iran 2/ & Trinidad and Tobago & & Belarus \\
\hline Ireland 2/ & Tunisia & & Bulgaria \\
\hline Israel & Turkey & & Dominican Republic \\
\hline Italy & Uganda & & Iran \\
\hline Jamaica & Ukraine 6/ & & Jordan \\
\hline Japan & United Arab Emirates & & Mozambique \\
\hline Jordan & United Kingdom & & Nicaragua \\
\hline Kazakhstan 2/ 6/ & Uruguay & & Pakistan \\
\hline Kenya & Yemen & & Romania \\
\hline Korea & Zambia & & South Africa \\
\hline Kuwait & & & Sudan \\
\hline & & & Zambia \\
\hline
\end{tabular}

Sources: IMF; and World Bank staff estimates.

1/ Defined as cases where the FSSA has been discussed by the Fund's Executive Board.

2/ The initial assessment was a part of the pilot program.

3/ Completion has been postponed for Argentina (FY01; interrupted by the financial crisis). Cote d'Ivoire (FY02; uncompleted for security reasons).

4/ Comprises Cameroon, Central African Republic, Chad, Republic of Congo, Equatorial Guinea, and Gabon. The regional

FSAP has been discussed by the Board; only the country modules remain to be completed.

5/ Part of WAEMU; will be assessed following the WAEMU FSAP.

6/ An FSAP Update is underway.

7/ Partial updates. 
Table 3. Implementation of the HIPC Initiative and MDRI (In millions of SDRs unless otherwise noted; as of March 31, 2008)

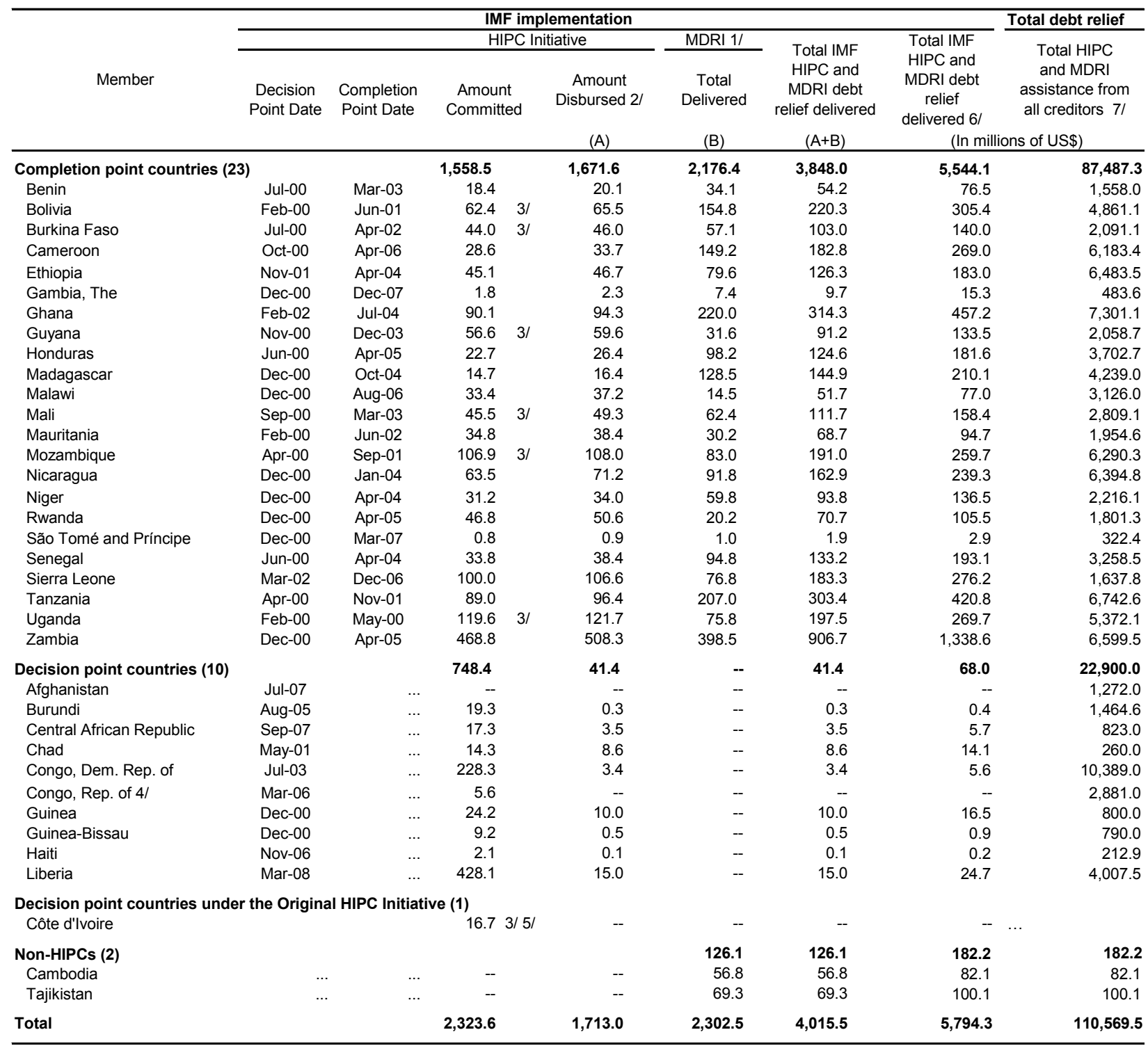

Source: IMF Finance and PDR Departments.

1/ Excludes remaining HIPC Initiative assistance delivered. Assistance was delivered in January 2006 except for to Mauritania, which received MDRI assistance in June 2006, and the countries which reached their respective completion points thereafter, which are: Cameroon (April 2006), Malawi (September 2006), Sierra Leone (December 2006), São Tomé and Príncipe (March 2007), and The Gambia (December 2007).

2/ Disbursed into HIPC Umbrella Account. Includes interest on amounts committed under the Enhanced HIPC Initiative.

3/ Amount includes commitment under the Original HIPC Initiative. Decision point and completion point dates refer to the Enhanced HIPC Initiative.

4/ No interim HIPC assistance has been provided yet by the IMF.

5/ Côte d'Ivoire reached its decision point under the Original HIPC Initiative in 1998; but did not reach its completion point under the Original HIPC Initiative, nor has it reached the decision point under the Enhanced HIPC Initiative.

6/ Derived using exchange rate of US\$ per SDR as of March 31, 2008 (1 SDR = USD 0.608088) for decision point countries, and as of dates of delivery of HIPC and MDRI assistance for other countries.

7/ Committed debt relief under the assumption of full participation of creditorn of full participation of creditors. 
Table 4. Current Financial Arrangements and PSIs

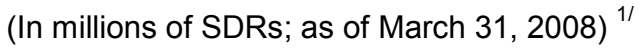

\begin{tabular}{|c|c|c|c|c|c|}
\hline \multirow[t]{2}{*}{ Member } & \multirow[t]{2}{*}{ Effective Date } & \multirow[t]{2}{*}{ Expiration Date } & \multirow{2}{*}{$\begin{array}{l}\text { Amount } \\
\text { Agreed }\end{array}$} & \multirow{2}{*}{$\begin{array}{l}\text { Undrawn } \\
\text { Balance }\end{array}$} & Total Credit \\
\hline & & & & & Outstanding ${ }^{2 /}$ \\
\hline
\end{tabular}

Stand-By Arrangements (6)

\begin{tabular}{|c|c|c|c|c|c|}
\hline Gabon & $5 / 7 / 07$ & $5 / 6 / 10$ & 77 & 77 & 10 \\
\hline Iraq & $12 / 19 / 07$ & $3 / 18 / 09$ & 475 & 475 & -- \\
\hline Macedonia, FYR & $8 / 31 / 05$ & $8 / 30 / 08$ & 52 & 41 & -- \\
\hline Paraguay & $5 / 31 / 06$ & 8/31/08 & 30 & 30 & -- \\
\hline Peru & $1 / 26 / 07$ & $2 / 28 / 09$ & 172 & 172 & -- \\
\hline Turkey & $5 / 11 / 05$ & $5 / 10 / 08$ & 6,662 & 2,248 & 4,223 \\
\hline
\end{tabular}

Extended Fund Facility Arrangements (2)

$\begin{array}{lrrrrr}\text { Albania } & 2 / 1 / 06 & 1 / 31 / 09 & 9 & 4 & 5 \\ \text { Liberia } & 3 / 14 / 08 & 3 / 13 / 11 & 343 & -- & 343\end{array}$

Poverty Reduction and Growth Facility (24)

\begin{tabular}{|c|c|c|c|c|c|}
\hline Afghanistan & $6 / 26 / 06$ & $6 / 25 / 09$ & 81 & 34 & 47 \\
\hline Albania & $2 / 1 / 06$ & $1 / 31 / 09$ & 9 & 4 & 49 \\
\hline Armenia & $5 / 25 / 05$ & $5 / 24 / 08$ & 23 & 3 & 98 \\
\hline Benin & $8 / 5 / 05$ & $8 / 4 / 09$ & 6 & 3 & 4 \\
\hline Burkina Faso & $4 / 23 / 07$ & $4 / 22 / 10$ & 15 & 11 & 27 \\
\hline Cameroon & 10/24/05 & 10/23/08 & 19 & 5 & 13 \\
\hline Central African Rep. & $12 / 22 / 06$ & $12 / 21 / 09$ & 36 & 16 & 29 \\
\hline Chad & 2/16/05 & $5 / 31 / 08$ & 25 & 21 & 33 \\
\hline Congo, Rep. of & $12 / 6 / 04$ & $6 / 5 / 08$ & 55 & 31 & 24 \\
\hline Gambia, The & $2 / 21 / 07$ & $2 / 20 / 10$ & 14 & 8 & 6 \\
\hline Grenada & $4 / 17 / 06$ & $4 / 16 / 09$ & 11 & 9 & 2 \\
\hline Guinea & $12 / 21 / 07$ & $12 / 20 / 10$ & 48 & 41 & 39 \\
\hline Haiti & $11 / 20 / 06$ & $11 / 19 / 09$ & 74 & 30 & 43 \\
\hline Kyrgyz Republic & 3/15/05 & $5 / 31 / 08$ & 9 & 1 & 89 \\
\hline Liberia & $3 / 14 / 08$ & $3 / 13 / 11$ & 239 & 32 & 207 \\
\hline Madagascar & $7 / 21 / 06$ & $7 / 20 / 09$ & 55 & 24 & 43 \\
\hline Malawi & $8 / 5 / 05$ & $8 / 4 / 08$ & 38 & 5 & 31 \\
\hline Mauritania & 12/18/06 & $12 / 17 / 09$ & 16 & 8 & 8 \\
\hline Moldova & $5 / 5 / 06$ & $5 / 4 / 09$ & 111 & 34 & 96 \\
\hline Nicaragua & 10/5/07 & $10 / 4 / 10$ & 72 & 60 & 54 \\
\hline Niger & $1 / 31 / 05$ & $5 / 31 / 08$ & 26 & 1 & 25 \\
\hline Rwanda & 6/12/06 & $6 / 11 / 09$ & 8 & 3 & 6 \\
\hline Sao Tome & $8 / 1 / 05$ & $7 / 31 / 08$ & 3 & 0 & 2 \\
\hline Sierra Leone & $5 / 10 / 06$ & $5 / 9 / 09$ & 31 & 22 & 23 \\
\hline Total financial arran & & & 8,843 & 3,454 & 5,579 \\
\hline \multicolumn{6}{|c|}{ Policy Support Instruments (5) } \\
\hline Cape Verde & 7/31/06 & $7 / 31 / 09$ & -- & -- & -- \\
\hline Mozambique & $6 / 26 / 07$ & $6 / 26 / 10$ & -- & -- & -- \\
\hline Senegal & $11 / 2 / 07$ & $11 / 2 / 10$ & -- & -- & -- \\
\hline Tanzania & 2/16/07 & $2 / 16 / 10$ & -- & -- & -- \\
\hline Uganda & $12 / 15 / 06$ & $12 / 15 / 09$ & -- & -- & -- \\
\hline
\end{tabular}


Table 5. Total Fund Credit and Loans Outstanding to the Ten Largest Borrowers

(In millions of SDRs; as of March 31, 2008) ${ }^{1 /}$

\begin{tabular}{|c|c|c|c|c|c|}
\hline \multirow[b]{2}{*}{ Member } & \multirow{2}{*}{$\begin{array}{c}\text { Non- } \\
\text { concessional } \\
\text { (GRA) } \\
\end{array}$} & \multirow{2}{*}{$\begin{array}{c}\text { Concessional } \\
\text { (PRGF, SAF, and Trust } \\
\text { Fund Loans) }\end{array}$} & \multicolumn{3}{|c|}{ Total } \\
\hline & & & $\begin{array}{l}\text { Outstanding } \\
\text { Amount }\end{array}$ & Quota & $\begin{array}{c}\text { In percent } \\
\text { of quota }\end{array}$ \\
\hline Turkey & $4,222.5$ & 0.0 & $4,222.5$ & $1,191.3$ & 354.4 \\
\hline Pakistan & 14.2 & 845.9 & 860.1 & $1,033.7$ & 83.2 \\
\hline Liberia & 342.8 & 207.3 & 550.0 & 129.2 & 425.7 \\
\hline Congo, Dem. Rep. of & 0.0 & 511.5 & 511.5 & 533.0 & 96.0 \\
\hline Dominican Republic & 399.5 & 0.0 & 399.5 & 218.9 & 182.5 \\
\hline Bangladesh & 0.0 & 316.7 & 316.7 & 533.3 & 59.4 \\
\hline Sudan $1 /$ & 232.6 & 59.2 & 291.8 & 169.7 & 172.0 \\
\hline Ukraine & 180.9 & 0.0 & 180.9 & $1,372.0$ & 13.2 \\
\hline Kenya & 0.0 & 168.8 & 168.8 & 271.4 & 62.2 \\
\hline Sri Lanka & 120.6 & 38.4 & 159.0 & 413.4 & 38.5 \\
\hline Total & $5,513.2$ & $2,147.8$ & $7,661.0$ & $5,865.9$ & 130.6 \\
\hline \multicolumn{6}{|l|}{ Memorandum Item: } \\
\hline All Fund members & $5,798.8$ & $3,982.6$ & $9,781.4$ & $\ldots$ & $\ldots$ \\
\hline
\end{tabular}

Source: IMF Finance Department.

1/ Member is in arrears on its total outstanding Fund credit (which excludes any overdue interest and other charges). 
Table 6. Consolidated Income and Expenses, FY2008-FY2014

Baseline Scenario

(in millions of U.S. dollars)

\begin{tabular}{|c|c|c|c|c|c|c|c|}
\hline & \multirow{2}{*}{$\frac{\text { Estimated }}{\text { FY } 08}$} & \multicolumn{3}{|c|}{ MTB Timeframe } & \multicolumn{3}{|c|}{ Projected 1/ } \\
\hline & & FY 09 & FY 10 & FY 11 & FY 12 & FY 13 & FY 14 \\
\hline A. Operational income 2/ & 845 & 681 & 706 & 806 & 958 & 1,025 & 1,034 \\
\hline 1. Lending income & 307 & 239 & 140 & 101 & 102 & 104 & 107 \\
\hline 2. Investment income $3 /$ & 432 & 320 & 426 & 517 & 610 & 646 & 650 \\
\hline 3. Interest free resources $4 /$ & 100 & 46 & 64 & 111 & 168 & 194 & 195 \\
\hline 4. Reimbursements 5/ & 6 & 76 & 76 & 76 & 78 & 80 & 82 \\
\hline B. Administrative expenses & 1,061 & 989 & 938 & 955 & 977 & 1,004 & 1,025 \\
\hline 1. Net administrative budget & 886 & 868 & 880 & 895 & 917 & 946 & 964 \\
\hline 2. Capital budget items expensed & 20 & 18 & 16 & 15 & 13 & 12 & 14 \\
\hline 3. Depreciation expense & 35 & 38 & 42 & 46 & 47 & 46 & 47 \\
\hline 4. Restructuring expenses $6 /$ & 120 & 65 & 0 & 0 & 0 & 0 & 0 \\
\hline C. Balance (A-B) 7/ & -216 & -309 & -232 & -150 & -19 & 21 & 9 \\
\hline \multicolumn{8}{|l|}{ Memorandum items: } \\
\hline Operational income from new income model $8 /$ & 0 & 71 & 175 & 292 & 418 & 482 & 488 \\
\hline Profits from gold sales $2 /$ & 0 & 0 & 2,197 & 2,197 & 2,197 & 0 & 0 \\
\hline U.S. dollar/SDR exchange rate $9 /$ & 1.57 & 1.65 & 1.65 & 1.65 & 1.65 & 1.65 & 1.65 \\
\hline SDR interest rate $10 /$ & 3.73 & 2.75 & 3.00 & 3.25 & 3.50 & 3.50 & 3.50 \\
\hline Fund credit (average stock, SDR billions) & 7.3 & 7.2 & 5.0 & 5.0 & 5.1 & 5.3 & 5.4 \\
\hline Capital expenditures (budget definition) & 46 & 59 & 52 & 44 & 44 & 44 & 44 \\
\hline Capital-related expenses $11 /$ & 55 & 56 & 58 & 61 & 60 & 58 & 61 \\
\hline
\end{tabular}

Sources: Finance Department and Office of Budget and Planning.

Note: Figures may not add to totals due to rounding.

1/ Assumes annual growth of 2.5 percent in the net administrative budget, reimbursements, and credit outstanding from FY12 onwards. Estimated expenses for external Annual Meetings of \$6 million are included in FY13 (\$5.4 million was included in FY10).

2/ Gold sales are assumed to be phased over 3 years beginning in FY10, at an average price of $\$ 850$ per ounce.

$3 /$ Incorporates the effect of a broader investment mandate from FY10 and a 3 percent pay-out from the endowment.

4/ Incorporates the reduction in remuneration expenses from SCA-1 resources and from retaining proceeds equal to the book value of gold in the GRA, and the increase in remuneration from net income shortfalls.

5/ Reimbursement of the GRA for the administrative expenses of the PRGF-ESF Trust is assumed from FY09.

6/ This profile is broadly consistent with the assumed phasing of staff separations in the Medium-Term Administrative, Restructuring, and Capital Budgets.

7/ Corresponds to net operational income, with a deduction for restructuring expenses in FY08 and FY09.

8/ Increase in operational income from broadening investments, the endowment funded by profits from gold sales, the remuneration reduction from the book value portion of gold sales, and reimbursement for PRGF-ESF Trust expenses.

9/ The US\$/SDR exchange rate is assumed to be unchanged from recent levels.

10/ The SDR interest rate is assumed to rise from current levels in FY09 to 3.5 percent in the medium term, which reflects the historical average level of the SDR interest rate in the past 15 years.

11/ The sum of capital budget items expensed and depreciation expense.

\section{CInternational Monetary Fund. Not for Redistribution}




\section{Annex: Summary of MCM Working Group Policy Recommendations}

In its October 2007 communiqué, the IMFC asked the Fund to reflect on the underlying causes and policy lessons from the financial market turmoil. In response, five MCM working groups, in close cooperation with the relevant FSF working groups and other stakeholders, studied the structural causes of the ongoing crisis. The following is a summary of the main lessons learned. ${ }^{21}$ These lessons are of a medium-term nature, and the shorter-term policy responses that may be required to help manage and mitigate the ongoing crisis are discussed in the Global Financial Stability Report ( $\underline{\text { GFSR }}$ ).

$\begin{array}{ll}\text { Findings } & \text { Lessons and Recommendations }\end{array}$

\section{Risk Management Practices}

Risk management practices in many financial institutions reflected shortcomings of both judgment and governance. Institutions relied too heavily on model-based strategies that were based on limited historical data, without due regard for their limitations. Hedging strategies were overly concentrated and, especially in the case of structured products, inadequate attention was paid to tail and liquidity risks.
Risk managers should challenge aggressively the assumptions underlying risk management and pricing models and scrutinize their firms' risk profile, including hedging strategies, counterparty risk, and possible second-round effects from market shocks.

Senior managers need to ensure that internal governance structures are robust and that information and decision-making responsibilities are well-defined and appropriate.

Supervisors need to take a more active role in monitoring risk management and encourage more rigorous stress testing, especially during "good times."

While also guarding against the risk of over-regulation, regulators may wish to consider whether the opacity and complexity of structured credit products, such as ABS CDOs undermine market discipline and require prudential or other measures.

\section{Valuation, Disclosure, and Accounting}

The accounting treatment of structured products, as well as shortcomings in valuation models and financial reporting, contributed to the depth and the duration of the current crisis.
Supervisors should ensure financial institutions develop robust pricing, risk management, and stress testing models. Consideration should be given to raising prudential norms (e.g., capital buffers) for structured finance products.

Supervisors should promote better internal processes within regulated entities for managing valuation modeling risk.

Cross-border convergence of accounting and regulatory standards, as well as bank disclosure requirements, should be sought, especially where global financial institutions are involved. Disclosure of off-balance sheet holdings, SIVs, and conduits should be enhanced.

Steps could be taken to improve price discovery and liquidity of hard-to-value securitized instruments, for example by seeking greater standardization and the development of a centralized registry.

\footnotetext{
${ }^{21}$ The Recent Financial Turmoil - Initial Assessment, Policy Lessons, and Implications for Fund Surveillance $(4 / 9 / 08)$.
} 


\section{Credit Rating Agency Practices}

Credit rating methodologies failed to capture the risks embodied in structured products. Investors in structured products relied too heavily on ratings, without appreciating their vulnerability to sharp price changes and multiple notch downgrades.
Credit rating agencies should improve rating methods and practices, and at a minimum introduce differentiated ratings for structured products, disseminate information on the susceptibility of their ratings to downgrades, and disclose greater detail about rating methodologies.

Approval and licensing procedures could be used to reduce potential conflicts of interest in the credit rating industry and spur improvements in transparency and the disclosure of ratings methodologies.

Authorities and the major international standard setters should review the use and effectiveness of credit ratings in prudential regulation, especially in light of possible changes to the ratings scales applied to structured products.

\section{Supervision and Crisis Management}

Consolidated supervision was inadequate, and supervisors did not adequately account for the risks associated with new financial instruments and did not address deterioration in underwriting standards. Gaps in crisis management and bank resolution frameworks were also exposed.
The Basel II framework will permit a more risk-sensitive approach to supervision and countries with internationally active banks will need to adopt it quickly. But the transition to Basel II will need to be carefully managed since partial or incomplete implementation would pose risks; the application of capital floors may need to be extended; and particular attention should be paid to the impact analysis from the parallel run period.

Supervisory practices, such as the frequency of on-site supervision and the use of external auditors, need to be strengthened, and supervisors need to be given adequate resources to perform their duties effectively.

Consolidated supervision and prudential reporting should be applied to off-balance sheet entities, with better regard to reputational and other contingent liabilities.

Bank resolution and deposit insurance frameworks need to be strengthened, and interagency coordination needs to be more effective. Central banks should remain well informed and involved.

Minimum underwriting and consumer protection standards should apply to all financial intermediaries to limit excessive risk taking and regulatory arbitrage.

\section{Central Bank Liquidity}

Shortcomings in existing emergency liquidity frameworks reduced the ability of central banks to respond effectively to disruptions in interbank markets.
Central banks need to be able to lend to a sufficiently broad set of counterparties and accept a sufficiently broad range of collateral, while taking care to avoid excessive counterparty/credit risk.

Care is needed to avoid unduly stigmatizing the use of central bank liquidity.

There would be merit in improving collaboration among central banks, including by establishing a more permanent set of emergency swap lines to address problems of liquidity in foreign currency, and seeking greater convergence in operational frameworks. 